\title{
ANALYSIS OF JIGLESS SPOT WELDING PROCESS PARAMETERS
}

\author{
Ehsaan-Reza BAGHERIAN \\ Inspection Technology \& Quality Assurance National Institute (ITQAN), Kingdom of Saudi Arabia, \\ ehsanreza@gmail.com
}

https://doi.org/10.37904/metal.2020.3657

\begin{abstract}
Jigless robot welding is one of the most demanding disciplines in the automation industry. Jigless processes offer significant benefits by reducing the cost of custom tooling and providing flexibility to process part variations with low batch sizes but make high demands on robotics and the know-how of suppliers and users. The main aim of this research project is to study plant layout and materials handling for jigless spot welding systems in order to investigate the best strategy in Alhasawi Company in Kuwait. This project was done to optimize the jigless spot welding and compare between the original layout of Al-Hasawi Company (semiautomated system) and the re-designed layout (fully automated system - Jigless robot welding). It is found that the jigless welding process has better performance and utilization, less process time and less defect rate.
\end{abstract}

Keywords: Jigless welding, spot welding, factory layout, automation, materials handling

\section{INTRODUCTION}

\section{Jigless Spot Welding}

Jigless spot welding is a combination of two robots; one does the welding part and the other one does the material handling to present the work piece to the robotic welder. Jigless spot welding is commonly used in various industries such as automotive manufacturing systems like Honda and Ford industries (Automated Car Production). Jigless welding pairs a robotic welder with a material handling robot that presents the workpiece to the welding robot. Optimal weld quality, lower cost and smaller system footprints are the significant returns on a company's investment when pairing a welding arm with a material handling robot. The practice of using a second robot to hold a robotic welding workpiece is a more precise way of accomplishing the same end result. A gripper or some sort of holding tool is placed on the material handling robot to grab or mount the workpiece and present it to the welding robot. By automating this process it is easier to maintain preset tolerances and quality standards on the finished part $[1,2,3]$.

\section{Alhasawi Group Company}

Alhasawi Group is one of the leading manufacturers in Kuwait, specializing in cooling and heating products and equipment such as refrigerators, water coolers, air conditioners, water heaters, water coolers. This research presents an approach to optimize jigless welding using a real-life example of Alhasawi group in Kuwait in Sabhan branch which only produces water heaters [4]. This report will study and compare

a. The original factory layout of water heater production (semi-automated system) and the re-designed layout (fully automated system - Jigless robot welding).

b. Jigless spot welding parameters and manual spot welding parameters such as utilization, process time, defect rate.

\section{EXPERIMENT}

This section presents the experimental work on factory layout and welding parameters using AutoCad and Excel software. 


\section{Factory Layout}

Factory layout is the arrangement of machines and equipment within a factory which includes the layout of departments within the factory site, the layout of machines within the departments and the layout of individual workplaces. Location of equipment is the placement of a facility with respect to customers, suppliers, and other facilities with which it interfaces. Decisions regarding plant location are taken by considering various factors. Facility location is generally the first step in facility planning [5,6]. In this research project, AutoCAD software is used to draw the initial layout (semi-automated system). In AutoCAD, first, the factory area borders are drawn. Then, the workstations distributed inside the border. In a second stage, the layout has been changed and re-designed for specific workstations, which contain spot welding and material handling form manual workstations to a robotic workstation (fully automated system - Jigless robot welding).

\section{Welding Parameters}

MS Excel is used for analysis and production calculation for rate [7]. Table 1 shows the data required for the excel analysis, which are the operation time and the number of identical machines and the defect rate for each system.

Table 1 Excel parameters

\begin{tabular}{|c|c|c|c|}
\hline Machine number & Machine name & Operation time (sec) & Number of machines \\
\hline 1 & Decoiler shearing & 46.8 & 1 \\
\hline 14 & Shearing & 4.9 & 1 \\
\hline 7 & 10-ton mechanical press & 72 & 1 \\
\hline 3 & c-type mechanical press 1 & 30.9 & 1 \\
\hline 23 & Roll former & 5.9 & 1 \\
\hline SW & Spot welding arm (Robot) & 25.3 & 3 \\
\hline $\mathrm{MH}$ & Material handling arm (Robot) & 25.9 & 3 \\
\hline 18 & Seam welding & 54 & 1 \\
\hline 22 & Edge former 1 & 45.9 & 1 \\
\hline 12 & Mechanical press & 38.9 & 1 \\
\hline 5 & c-type mechanical press2 & 30.9 & 1 \\
\hline 52 & Powder paint 1 & 134.6 & 1 \\
\hline 53 & Powder paint 2 & 134.6 & 1 \\
\hline 51 & Powder paint 3 & 134.6 & 1 \\
\hline 54 & nibbler & 61.9 & 1 \\
\hline 61 & Hydraulic press 200TN & 45.9 & 1 \\
\hline 62 & Trimming & 45.9 & 1 \\
\hline 65 & Hydraulic press & 55.9 & 1 \\
\hline 64 & Swaging & 5.1 & 1 \\
\hline 28 & Japan daihen (OTC) ROBOT & 119.8 & 1 \\
\hline 25 & MAG straightening burning & 748.8 & 1 \\
\hline SW & Spot welding (manual) & 61.9 & 3 \\
\hline 32 & MAG horizontal type double & 748.8 & 4 \\
\hline 40 & Leak testing & 518.4 & 1 \\
\hline 59 & Heating element tightening & 59.9 & 1 \\
\hline Assembly & Assembly & 1109.9 & 5 \\
\hline 50 & Packaging & 174.9 & 1 \\
\hline
\end{tabular}




\section{RESULTS AND DISCUSSION}

\section{Factory Layout Using AutoCAD}

The optimal facility layout is an effective tool in cost reduction by enhancing the productivity. Facility layout design involves a systematic physical arrangement of different departments, workstations, machines, equipment, storage areas and common areas in a manufacturing industry [8]. There are couple of methods for layout improvement such as re-routing of material flow in a given facility that can improve the efficiency of material movement. When re-routing is not efficient, the other more drastic way is the re-layout. In most of cases the re-layout requires more time, effort and is more expensive [9].

Figure 1a shows the initial draft which is provided by Alhasawi group company for semi-automated system and Figure 1b shows the re-designed layout for fully automated system - Jigless robot welding. In a redesigned layout, there are 3 spot welding machines. So only the machines which are really working are considered and the other machines put in the storage. The machine snow is suitable for their demand or maybe slightly higher. However, if they change their demand to a higher number or if there is machine failure they can take them from the storage. It is reorganized that, the machines in a line based on the sequence of the process by this strategy; after the sheet metal cutting and shearing section, the parts will move in two different directions, one for the inner tank and one for the outer body cylinder and covers. The outer body units will move to the powder paint section and then to the assembly. However, the inner tank will go directly to the assembly where they will be collected. Moreover, in the new design it is considered to put aisles where the aisles means the allowance space that the material handling can move through, and in our case, it is the operator, and the robotic material handling arm of jigless. The operator aisles based on facilities planning textbook was 3 feet equal to $914.4 \mathrm{~mm}$ [10]. The arm allies based on the robot's maximum and minimum reach of it. This design to minimize material movement through machines and reduce accidents that might accrue in the workplace which means less cost for the company. Also, the assembly conveyor will be closer to the storage so that the final product can be transformed easily and avoid defects in the product. A new factory layout can be created from an existing AutoCAD 2D layout. If the AutoCAD layout contains any 2D assets or chainable assets placed from the System Assets library in AutoCAD Factory, the assets are replaced with their 3D equivalents when the drawing file is opened in Inventor Factory.

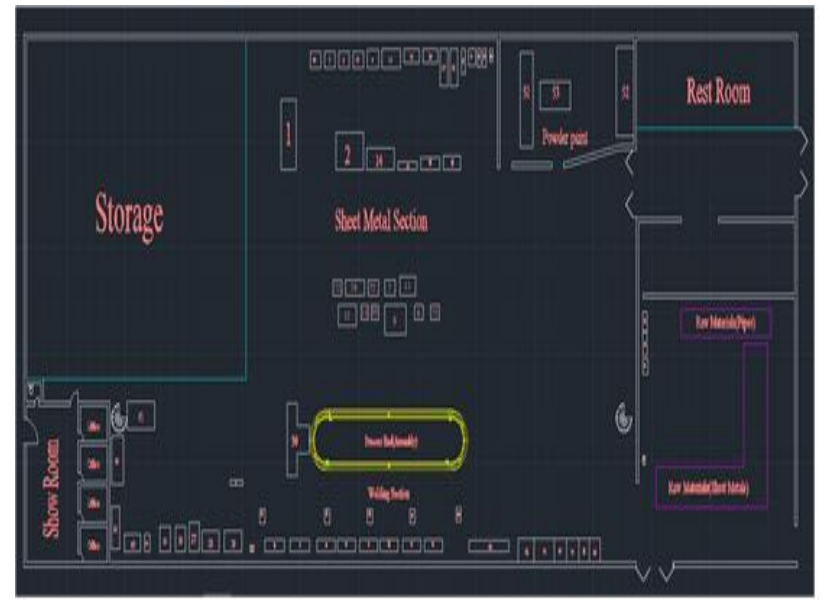

Figure 1a Initial Layout

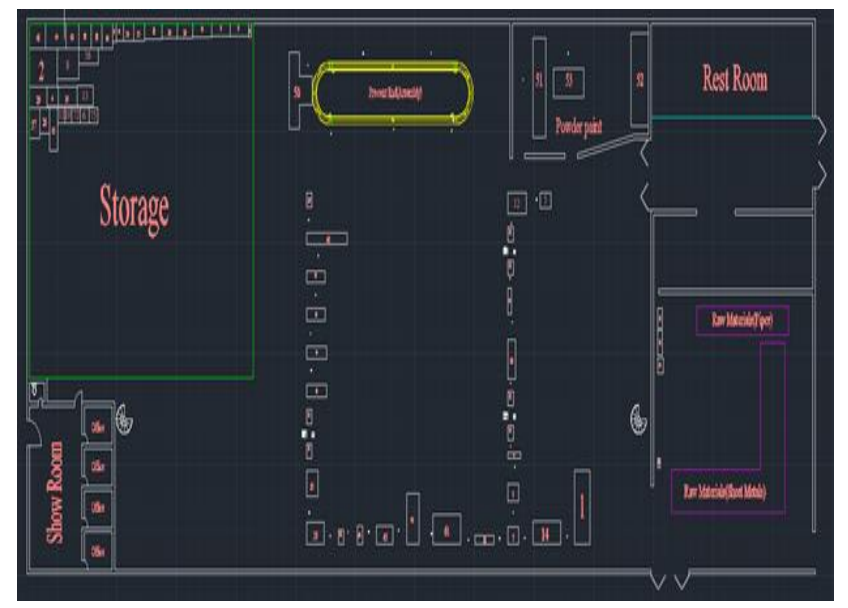

Figure 1b Re-Designed Layout

\section{Welding Parameters Using MS-Excel}

Data as shown in Table 1 inserted for the demand of 500 water heaters per month and 208 hours work per month. Because all the employees work 26 days per month for 8 hours per day. The following tables show the calculated data for both semi-automated system and fully automated system - Jigless robot welding. 
In these tables; (a) push is the number of products that will be transferred to the end customer. (b) For the scrap rate, the defect rate divides $2 \%$ all over the machines in the system. (c) The Res is the amount which inserts the quantity for each machine. After inserting all the data which calculated, the throughput time and the work in process as an output, which equals 0.051 hours, and 62.15 units will be calculate. To calculate a factory's utilization rate, you multiply the plant's actual output per month or year times 100 and divide this number by the plant's maximum output per month or year. Table 2 will present the input for semi-automated spot welding system and fully automated system and Table $\mathbf{3}$ will present Output for semi-automated spot welding system and fully automated system.

Table 2 Input for semi-automated spot welding system (S) and fully automated system (F)

\begin{tabular}{|c|c|c|c|c|c|c|c|c|c|c|c|c|c|c|}
\hline Process & $\begin{array}{l}\text { Water } \\
\text { Heater }\end{array}$ & & & & \begin{tabular}{c|} 
Flow \\
time \\
interval
\end{tabular} & Month & & \begin{tabular}{|l|} 
Through \\
put time
\end{tabular} & 0.051 & & $\mathrm{Hr}$ & & & \\
\hline Structure & Tree & & & & $\begin{array}{c}\text { Oper } \\
\text { time } \\
\text { interval }\end{array}$ & Hour & & \begin{tabular}{|l|} 
Work in \\
process
\end{tabular} & 62.15 & & & & & \\
\hline Drive & Push & & & & $\begin{array}{c}\text { Opr int } \\
\text { per flow }\end{array}$ & 208 & & & & & & & & \\
\hline Flow in & 500 & \begin{tabular}{|c|} 
Per \\
month
\end{tabular} & & & & & & & & & & & & \\
\hline Name & Type & Index & Previous & $\begin{array}{l}\text { Push } \\
\text { in }\end{array}$ & Opr time & $\begin{array}{l}\text { Scrap } \\
\text { rate }\end{array}$ & Res type & \begin{tabular}{|c|} 
Res \\
amount
\end{tabular} & \begin{tabular}{|l} 
Flow \\
Rem
\end{tabular} & Ratio & $\begin{array}{l}\text { Unit } \\
\text { flow }\end{array}$ & $\begin{array}{l}\text { Unit } \\
\text { time }\end{array}$ & $\begin{array}{l}\text { Oper } \\
\text { Flow }\end{array}$ & WIP \\
\hline $\begin{array}{c}\text { Start } \\
\text { water } \\
\text { heater }\end{array}$ & Dummy & 0 & - & 1 & - & - & - & - & - & 1 & 1 & & - & - \\
\hline 1 & \multirow{26}{*}{ Op } & 1 & 0 & \multirow{25}{*}{0} & \multirow{7}{*}{\begin{tabular}{|c|}
0.013 \\
0.00138 \\
0.02 \\
0.008611 \\
0.00166 \\
0.01722 \\
0.015
\end{tabular}} & \multirow{26}{*}{$\begin{array}{c}0.00059 \\
\%(\mathrm{~S}) \\
0.00029 \\
\%(\mathrm{~F})\end{array}$} & M1 & 1 & \multirow{26}{*}{$0.0 \%$} & \multirow{26}{*}{$\begin{array}{c}0.999994118 \\
(\mathrm{~S}) \\
0.99999706 \\
(\mathrm{~F})\end{array}$} & 1 & 0.013 & 2.4038 & 0.0313 \\
\hline 14 & & 2 & 1 & & & & M14 & 1 & & & 1 & \begin{tabular}{|l|}
0.0014 \\
\end{tabular} & 2.4038 & 0.0033 \\
\hline 7 & & 3 & 2 & & & & M7 & 1 & & & 1 & 0.02 & 2.4038 & 0.0481 \\
\hline 3 & & 4 & 3 & & & & M3 & 1 & & & 1 & \begin{tabular}{|l|}
0.0086 \\
\end{tabular} & 2.4038 & 0.0207 \\
\hline 23 & & 5 & 4 & & & & M23 & 1 & & & 1 & \begin{tabular}{|l|}
0.0017 \\
\end{tabular} & 2.4038 & 0.004 \\
\hline SW & & 6 & 5 & & & & SW & 3 & & & 1 & 0.0172 & 2.4038 & 0.0414 \\
\hline 18 & & 7 & 6 & & & & M18 & 1 & & & 1 & \begin{tabular}{|l|}
0.015 \\
\end{tabular} & 2.4038 & 0.0361 \\
\hline 22 & & 8 & 7 & & \multirow{5}{*}{\begin{tabular}{|c|}
0.01277 \\
0.01083 \\
0.008611 \\
0.0374 \\
0.0374 \\
\end{tabular}} & & M22 & 1 & & & 1 & \begin{tabular}{|l|}
0.0128 \\
\end{tabular} & 2.4038 & 0.0307 \\
\hline 12 & & 9 & 8 & & & & M12 & 1 & & & 1 & 0.0108 & 2.4038 & 0.026 \\
\hline 5 & & 10 & 9 & & & & M5 & 1 & & & 1 & 0.0086 & 2.4037 & 0.0207 \\
\hline 52 & & 11 & 10 & & & & M52 & 1 & & & 1 & \begin{tabular}{|l|}
0.0374 \\
\end{tabular} & 2.4037 & 0.0899 \\
\hline 53 & & 12 & 11 & & & & M53 & 1 & & & 0.9999 & 0.0374 & 2.4037 & 0.0899 \\
\hline 51 & & 13 & 12 & & 0.0374 & & M51 & 1 & & & \begin{tabular}{|l|}
0.9999 \\
\end{tabular} & 0.0374 & 2.4037 & 0.0899 \\
\hline 54 & & 14 & 3 & & 0.0172 & & M54 & 1 & & & 1 & \begin{tabular}{|l|}
0.0172 \\
\end{tabular} & \begin{tabular}{|l|}
2.4037 \\
\end{tabular} & 0.0413 \\
\hline 61 & & 15 & 14 & & \begin{tabular}{|l|}
0.01277 \\
\end{tabular} & & M61 & 1 & & & 1 & \begin{tabular}{|l|}
0.0128 \\
\end{tabular} & 2.4038 & 0.0307 \\
\hline 62 & & 16 & 15 & & \begin{tabular}{|l|}
0.01277 \\
\end{tabular} & & M62 & 1 & & & 1 & 0.0128 & 2.4038 & 0.0307 \\
\hline 65 & & 17 & 16 & & \begin{tabular}{|l|}
0.01555 \\
\end{tabular} & & M65 & 1 & & & 1 & 0.0155 & 2.4038 & 0.0374 \\
\hline 64 & & 18 & 17 & & \begin{tabular}{|l|}
0.00144 \\
\end{tabular} & & M64 & 1 & & & 1 & \begin{tabular}{|l|l|}
0.0014 \\
\end{tabular} & 2.4037 & 0.0035 \\
\hline 28 & & 19 & 18 & & 0.0333 & & M28 & 1 & & & 1 & 0.0333 & 2.4037 & 0.08 \\
\hline 25 & & 20 & 19 & & 0.208 & & M25 & 1 & & & \begin{tabular}{|l|}
0.9999 \\
\end{tabular} & \begin{tabular}{|l|}
0.208 \\
\end{tabular} & \begin{tabular}{|l|}
2.4037 \\
\end{tabular} & 0.5 \\
\hline MAG & & 21 & 6 & & 0.208 & & M32 & 4 & & & 1 & 0.208 & 2.4038 & 0.5 \\
\hline 40 & & 22 & 21 & & 0.144 & & M40 & 1 & & & 1 & 0.144 & 2.4037 & 0.3461 \\
\hline 59 & & 23 & 22 & & \begin{tabular}{|l|}
0.01666 \\
\end{tabular} & & M59 & 1 & & & 1 & 0.0167 & 2.4037 & 0.04 \\
\hline Assembly & & 24 & 13 & & 0.308333 & & Assembly & 2 & & & \begin{tabular}{|l|}
0.9999 \\
\end{tabular} & \begin{tabular}{|l|}
0.3083 \\
\end{tabular} & \begin{tabular}{|l|}
2.4037 \\
\end{tabular} & 0.7411 \\
\hline Assembly & & 25 & 23 & & 0.308333 & & Assembly & 3 & & & \begin{tabular}{|l|}
0.9999 \\
\end{tabular} & 0.3083 & 2.4037 & 0.7411 \\
\hline 50 & & 26 & 25 & 500 & 0.0486 & & M50 & 1 & & & \begin{tabular}{|c|}
501 \\
501
\end{tabular} & \begin{tabular}{|l|}
24.349 \\
\end{tabular} & 1204.3 & 58.53 \\
\hline $\begin{array}{c}\text { End water } \\
\text { heater }\end{array}$ & Dummy & 27 & - & 0 & - & - & - & - & - & 1 & 0 & 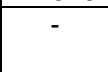 & - & - \\
\hline
\end{tabular}

This table shows the utilization of each machine, where M50 is the busiest machine since it has a large percent of utilization, which equals to $5853 \%$, while the others can be available whenever they get a task because of less than $100 \%$ utilization. In our project, we will focus on the spot welding machine where it has a utilization of $4 \%$. By replacing the semi-automated spot welding system to jigless spot welding system, which contains two robotic arms, one for spot welding and the other for material handling.

The best jigless was the spot-welding arm (Motoman MS80 $\mathrm{w}$ ) which payload $=72 \mathrm{Kg}$, horizontal reach $=$ $2236 \mathrm{~mm}$, and price = US \$12,700. Also, we chose the material handling arm (Motoman IA20) which has a payload $=20 \mathrm{Kg}$, horizontal reach $=910 \mathrm{~mm}$, and price $=$ US $\$ 19,999$. As a result of this replacement the defect 
rate decreases, the throughput time decreases where it becomes 0.051 hours, and the work in process decreases to 62.14 units. From these analysis it is observed that the utilization for all machines is still less than $100 \%$, except for M50 (The same as semi-automated machine has $5853 \%$ utilization which is used in MS80W robot). The MS80W is weighing $580 \mathrm{Kg}$, it has an $80 \mathrm{~kg}$ payload, and it also has a small footprint and is very compact, which make it ideal for high-density layouts. It can reach $2236 \mathrm{~mm}$ horizontally. In other design we used other types of robot such as YASKAWA VS100 robot which is VS100 is a unique thin design optimizes automotive applications using DC spot guns with small servo actuators.

The robot weighs $780 \mathrm{Kg}$, it can handle a payload equal to $110 \mathrm{Kg}$ and it can reach $2236 \mathrm{~mm}$ horizontally or ABB IRB 6640-235 robot which is a robot for spot welding application. It weighs $1310 \mathrm{Kg}$. It can take any heavy work that needs a payload of up to $235 \mathrm{~kg}$. It has a crash resistance, an easy maintenance, and simplified forklift pockets. It has a reach of $2550 \mathrm{~mm}$ and can bend fully backward, which enables it the ability to decrease its footprint and fit into a tight production line. The FANUC R-2000iB/200R is another robot used which is a rack-mount robot with a high payload capacity which equals to $200 \mathrm{Kg}$, it weighs $1540 \mathrm{Kg}$, and it can reach $3095 \mathrm{~mm}$ horizontally. Also, for the spot welding and material handling arms, the utilization is $2 \%$. Table 4 compares semi-automated system and fully automated system - Jigless robot welding.

Table 3 Output for semi-automated spot welding system (S) and fully automated system (F)

\begin{tabular}{|c|c|c|c|c|c|c|c|c|c|c|c|c|}
\hline Resource & $\begin{array}{c}\text { Number } \\
\text { Used }\end{array}$ & $\begin{array}{c}\text { Max } \\
\text { number }\end{array}$ & $\begin{array}{c}\text { Unit / } \\
\text { Hours / } \\
\text { Month }\end{array}$ & $\begin{array}{c}\% \\
\text { Avail }\end{array}$ & $\begin{array}{c}\% \mathrm{Mx} \\
\text { Unit }\end{array}$ & $\begin{array}{c}\text { Unit Avail } \\
\text { Hours / } \\
\text { Month }\end{array}$ & $\begin{array}{c}\text { Max } \\
\text { Avail } \\
\text { Hours / } \\
\text { Month }\end{array}$ & $\begin{array}{c}\text { Res Avail } \\
\text { Hours / } \\
\text { Month }\end{array}$ & $\begin{array}{l}\text { Res used } \\
\text { Hours / } \\
\text { Month } \\
\text { (S) }\end{array}$ & $\begin{array}{c}\text { Res } \\
\text { Utilization } \\
\text { (S) }\end{array}$ & $\begin{array}{l}\text { Res used } \\
\text { Hours / } \\
\text { Month } \\
(F)\end{array}$ & $\begin{array}{c}\text { Res } \\
\text { Utilization } \\
(F)\end{array}$ \\
\hline Assembly & 5 & \multirow{25}{*}{1} & \multirow{25}{*}{208} & \multirow{25}{*}{$\begin{array}{c}100 \\
\%\end{array}$} & \multirow{25}{*}{$\begin{array}{c}100 \\
\%\end{array}$} & \multirow{25}{*}{\multicolumn{2}{|c|}{208.00}} & 1040.00 & 770.79 & $74 \%$ & 770.81 & $74 \%$ \\
\hline M1 & 1 & & & & & & & \multirow{23}{*}{208.00} & 6.50 & $3 \%$ & 6.50 & $3 \%$ \\
\hline M12 & 1 & & & & & & & & 5.41 & $3 \%$ & 5.41 & $3 \%$ \\
\hline M14 & 1 & & & & & & & & 0.69 & $0 \%$ & 0.69 & $0 \%$ \\
\hline M18 & 1 & & & & & & & & 7.50 & $4 \%$ & 7.50 & $4 \%$ \\
\hline M22 & 1 & & & & & & & & 6.38 & $3 \%$ & 6.38 & $3 \%$ \\
\hline M23 & 1 & & & & & & & & 0.83 & $0 \%$ & 0.83 & $0 \%$ \\
\hline M25 & 1 & & & & & & & & 103.99 & $50 \%$ & 104 & $50 \%$ \\
\hline M28 & 1 & & & & & & & & 16.65 & $8 \%$ & 4.31 & $2 \%$ \\
\hline M3 & 1 & & & & & & & & 4.31 & $2 \%$ & 16.65 & $8 \%$ \\
\hline M32 & 5 & & & & & & & & 415.99 & $50 \%$ & 415.99 & $50 \%$ \\
\hline M40 & 1 & & & & & & & & 72.00 & $35 \%$ & 72.00 & $35 \%$ \\
\hline M5 & 1 & & & & & & & & 4.31 & $2 \%$ & 4.31 & $2 \%$ \\
\hline M50 & 1 & & & & & & & & 12174.30 & $5853 \%$ & 12174.30 & $5853 \%$ \\
\hline M51 & 1 & & & & & & & & 18.70 & $9 \%$ & 18.70 & $9 \%$ \\
\hline M52 & 1 & & & & & & & & 18.70 & $9 \%$ & 18.70 & $9 \%$ \\
\hline M53 & 1 & & & & & & & & 18.70 & $9 \%$ & 18.70 & $9 \%$ \\
\hline M54 & 1 & & & & & & & & 8.60 & $4 \%$ & 8.60 & $4 \%$ \\
\hline M59 & 1 & & & & & & & & 8.33 & $4 \%$ & 8.33 & $3 \%$ \\
\hline M61 & 1 & & & & & & & & 6.38 & $3 \%$ & 6.38 & $4 \%$ \\
\hline M62 & 1 & & & & & & & & 6.38 & $3 \%$ & 8.33 & $0 \%$ \\
\hline M64 & 1 & & & & & & & & 0.72 & $0 \%$ & 0.72 & $4 \%$ \\
\hline M65 & 1 & & & & & & & & 7.77 & $4 \%$ & 7.77 & $4 \%$ \\
\hline M7 & 1 & & & & & & & & 10.00 & $5 \%$ & 10.00 & $5 \%$ \\
\hline SW & 3 & & & & & & & 624.00 & 25.83 & $4 \%$ & 10.58 & $2 \%$ \\
\hline
\end{tabular}

Table 4 Comparison between semi-automated system and fully automated system - Jigless robot welding

\begin{tabular}{|c|c|c|c|c|c|}
\hline The system & Work in process & Throughput time & Defect rate & Utilization & Process time \\
\hline $\begin{array}{c}\text { Semi-automated } \\
\text { spot welding }\end{array}$ & 62.15423498 units & $\begin{array}{c}3.0965463 \\
\text { minutes }\end{array}$ & $0.00059 \%$ & $4 \%$ & 1.0332 minutes \\
\hline $\begin{array}{c}\text { Fully automated } \\
\text { system - Jigless } \\
\text { robot welding }\end{array}$ & 62.13724512 units & $\begin{array}{c}3.09619806 \\
\text { minutes }\end{array}$ & $0.00029 \%$ & $\begin{array}{c}2 \%+2 \% \\
=4 \%\end{array}$ & $\begin{array}{c}0.42324 \text { minutes }+ \\
0.4332 \text { minutes }= \\
0.85644 \text { minutes }\end{array}$ \\
\hline
\end{tabular}




\section{CONCLUSION AND FUTURE WORK}

Experimental results have revealed the following features:

1. Based on the experimental results, the jig-less welding method compare to the semi-automated welding offers most of the advantages of robotic welding such as; (a) Faster welding cycle time, (b) Increase in production with minimal / no breaks, (c) Less wasted material, (d) Consistent weld seams, (e) Increase in safety for human workers, (f) Greater precision in welding and (g) Flexibility in manipulating and handling a high variety of different work-pieces with less cost.

2. Regarding to the results from excel and after comparing the two systems it is considered that the Semiautomated spot welding has more throughput time.

3. Results showed that, the work in process units, defect rate and operation time of the Jigless spot welding system is better than Semi-automated spot welding.

4. From the AutoCAD results it can be concluded that the re-designed layout for Jigless spot welding have less material handling, less accident and injuries, and have less overall production cost.

5. As for future work, this research can be extended by comparing Semi-automated spot welding and fully automated system - Jigless robot welding with Manual spot welding.

\section{ACKNOWLEDGEMENTS}

This research project would not have been possible without the support of Alhasawi Group Kuwait company engineers and American University of the Middle East. Their guidance helped us throughout this research. The authors would like to thank to Chairman of company for his valuable comments and suggestions to improve the quality of the paper.

\section{REFERENCES}

[1] YASKAWA [Application Brochure]. Welding Lines and Systems Efficient, process-reliable, fully synchronized. 2017.

[2] YASKAWA ELECTRIC CORPORATION. [online]. Available from: https://www.yaskawa.eu.com/

[3] FABRICATING \& METALWORKING MAGAZINE. [online]. Available from: www.fabricatingandmetalworking.com/

[4] ALHASAWI GROUP OF COMPANY. [online]. Available from: https://www.alhasawi.com/

[5] KULKARNI, M. H., BHATWADEKAR, S. G., THAKUR, H. M. A Literature Review Of Facility Planning and Plant Layouts. International Journal Of Engineering Sciences \& Research Technology. 2015.

[6] HERAGU, S. S., KUSIAK, A. Machine Layout Problem in Flexible Manufacturing Systems. International Journal of Operation Research. 1998, vol. 36, no. 2, pp. 258-268.

[7] BISSETT, B. D. Automated Data Analysis using Excel. Chapman and Hall/CRC, 1st Edition, 2007.

[8] NAIK, B. S., KALLURKAR, S. A literature Review on Effcient Plant Layot Design. International Journal of Industrial Engineering Research and Development. 2016, vol. 7, no. 2, pp. $43-51$.

[9] ZHANG, M., BATTA, R., NAGI, R., Designing manufacturing facility layouts to mitigate congestion. International Journal of IIE Transactions. 2009, vol. 43, no.10, pp. 689-702.

[10] TOMPKINS, J. A., WHITE, J. A., BOZER, Y. A., TANCHOCO, J. M. A. Facilities Planning, 4th Edition, 2010. 